\title{
ANÁLISE DA MICROBIOTA FECAL DE CRIANÇAS ALÉRGICAS E NÃO ALÉRGICAS ÀS PROTEÍNAS DO LEITE DE VACA
}

Tese apresentada ao Programa de Pósgraduação em Microbiologia do Instituto de Ciências Biomédicas da Universidade de São Paulo, para obtenção do Título de Doutor em Ciências.

Área de Concentração: Microbiologia

Orientador: Prof. Dr. Gabriel Padilla Maldonado Coorientadora: Profa. Dra. Viviane Nakano Orientador: Prof. Dr. Mario Julio Avila-Campos (in memoriam) 


\section{RESUMO}

CARDOSO, N. S. Análise da microbiota fecal de crianças alérgicas e não alérgicas às proteínas do leite de vaca. 2019. $92 \mathrm{f}$. Dissertação (Doutorado em Microbiologia) Instituto de Ciências Biomédicas, Universidade de São Paulo, 2019.

A microbiota intestinal está envolvida na regulação de várias funções fisiológicas, incluindo a degradação de substâncias não digeríveis, produção de ácidos graxos de cadeia curta, redução da colonização de patógenos por conta da competição pelos sítios de adesão e permeabilidade intestinal. É composta predominantemente por bactérias anaeróbias sendo os filos Bacteroidetes e Firmicutes os mais prevalentes. A composição da microbiota intestinal e fecal pode variar em quantidade e especificidade nos sítios anatômicos. Neste estudo foi analisada a composição bacteriana das microbiotas fecais em crianças com e sem alergia às proteínas do leite de vaca. Foi realizado o isolamento bacteriano para os gêneros Lactobacillus, Bifidobacterium, Bacteroides/Parabacteroides e Clostridium, análise quantitativa das fezes por PCR em Tempo Real e a filogenia por AP-PCR dos isolados de Bifidobacterium e Lactobacillus de ambos os grupos estudados. Das 25 fezes de crianças com alergia, 14 (56\%) delas apresentaram espécies de Lactobacillus, 19 (76\%) de Bifidobacterium, 15 (60\%) de Clostridium, 24 (96\%) de Bacteroides e/ou de Parabacteroides. Já no grupo de crianças não alérgicas 20 (80\%) foram positivas para Lactobacillus, 23 (92\%) para Bifidobacterium, 9 (36\%) para Clostridium, 22 (88\%) para Bacteroides e/ou Parabacteroides. Em ambos os grupos na faixa etária de 6 a 10 anos de idade, as amostras fecais apresentaram maior diversidade de espécies, observando-se a presença de Lactobacillus spp., L. rhamnosus, L. casei, Bifidobacterium spp., B. infantis, Parabacteroides distasonis, Bacteroides fragilis, B. vulgatus, $C$. innocuum, e $C$. septicum. A análise quantitativa dos microrganismos realizada nas fezes mostrou diferenças estatísticamente significativas para Clostridium perfringens ( $p=0,037)$, Clostridium Cluster I $(p=0,005)$, Escherichia coli $(p=0,001) \mathrm{e}$ Bacteroidetes $(p=0,051)$. Os dendrogramas obtidos com as espécies de Lactobacillus e Bifidobacterium de ambos os grupos de crianças analisados, mostraram uma diversidade genética heterogênea e a presença de clones 
bacterianos, pertencentes na maioria das vezes, por bactérias isoladas $\mathrm{d}$ mesmo paciente. Na literatura mundial se observam escassos estudos sol composição da microbiota intestinal e/ou fecal de crianças com alergia ao leite de vaca. Certamente, este estudo comparativo poderá servir como base para pesquisas mais profundas nesta linha de investigação. 
Palavras chave: Microbiota intestinal; Microbiota fecal; Alergia alimentar; Alergia as proteínas do leite de vaca; Crianças alérgicas. 
CARDOSO, N. S. Fecal microbiota analysis of children allergic and nonallergic to cow's milk proteins. 2019. 92 p. Dissertação (Doutorado em Microbiologia) Instituto de Ciências Biomédicas, Universidade de São Paulo, 2019.

The intestinal microbiota is involved in regulating of several physiologic functions, including the degradation of substances not digestible, production of fat acids of short chain, reduction of the colonization of pathogens due to the competition by the sites of adhesion and intestinal permeability. It is composed predominantly of anaerobic bacteria being the most prevalent phylum Bacteroidetes and Firmicutes. The composition of the intestinal and fecal microbiota may vary in quantity and specificity in anatomical sites. In this study we analyzed the bacterial composition of fecal microbiotas in children with and without allergy to cow's milk proteins. Bacterial isolation was performed for the genera Lactobacillus, Bifidobacterium, Bacteroides/Parabacteroides and Clostridium, quantitative analysis of feces by Real-time PCR and phylogeny by AP-PCR of Bifidobacterium and Lactobacillus isolates from both groups studied. Of the 25 feces of children with allergies, 14 (56\%) of them presented Lactobacillus species, 19 (76\%) of Bifidobacterium, 15 (60\%) of Clostridium, 24 (96\%) of Bacteroides and/or Parabacteroides. In the group of non-allergic children 20 (80\%) were positive for Lactobacillus, 23 (92\%) for Bifidobacterium, 9 (36\%) for Clostridium, 22 (88\%) for Bacteroides and/or Parabacteroides. In both groups aged 6 to 10 years, fecal samples showed a greater diversity of species, observing the presence of Lactobacillus spp., L. rhamnosus, L. casei, Bifidobacterium spp., B. infantis, Parabacteroides distasonis, Bacteroides fragilis, B. vulgatus, C. innocuum, e $C$. septicum. The quantitative analysis of the microorganisms performed in the feces showed statistically significant differences for Clostridium perfringens ( $p=0,037)$, Clostridium Cluster I ( $p=$ $0,005)$, Escherichia coli $(p=0,001)$ e Bacteroidetes $(p=0,051)$. The dendrograms obtained with the species of Lactobacillus and Bifidobacterium from both groups of children analyzed, showed heterogeneous genetic diversity and the presence of bacterial clones, belonging most of the time, by isolated bacteria from the same patient. In the worldwide literature, there are scarce 
studies on the composition of intestinal and/or fecal microbiota of children v cow's milk allergy. Certainly, this comparative study could serve as a basis . deeper research in this line of research.

Keywords: Intestinal microbiota, Faecal microbiota, Food Allergy, Allergy the proteins of cow's milk, Allergic children. 


\section{INTRODUÇÃO}

A alergia ou hipersensibilidade alimentar constitui-se uma resposta imunológica adversa às proteínas presentes nos alimentos, causando vários sintomas ao paciente (WASERMAN e WATSON, 2011). Existem outras reações adversas aos alimentos que podem ocorrer sem o envolvimento do sistema imune do hospedeiro, tais como: deficiências enzimáticas digestivas (ex.: intolerância à lactose) e presença de toxinas (ex.: intoxicação alimentar por estafilococos), entre outras (FERREIRA et al., 2007).

Embora a alergia alimentar possa ser desencadeada por praticamente a maioria dos alimentos, os mais significativos são: leite de vaca, ovo, amendoim, mariscos, peixes, trigo e soja (RONA et al., 2007; TAYLOR-BLACK e WANG, 2012). Dentre eles, a alergia ao leite de vaca é a que apresenta maior prevalência, por ser o primeiro alimento introduzido na dieta em idade pediátrica, e pelo seu elevado potencial alergênico. As reações alérgicas causadas pelas proteínas presentes no leite de vaca (LV) podem ou não ser mediadas pela imunoglobulina $\mathrm{E}(\mathrm{IgE})$, a qual produz sintomas característicos em cada tipo de reação alérgica (HEINE et al., 2002; BRILL et al., 2008; JEONG et al., 2017). Também fatores genéticos, assim como a quantidade e frequência de exposição aos alérgenos alimentares podem influenciar uma resposta alérgica observada nos primeiros anos de vida.

Os indivíduos alérgicos às proteínas do leite de vaca são submetidos a uma dieta de exclusão do leite e derivados, a fim de eliminar ou amenizar os sintomas. A eliminação de alguns componentes do LV na dieta de crianças, como por exemplo, o cálcio e a lactose, podem levar à deficiência de crescimento da criança e à disbiose da microbiota intestinal, aumentando o risco de desenvolver futuramente outras patologias (ISOLAURI et al., 1998; TURNBAUGH et al., 2007).

A microbiota intestinal é o conjunto de microrganismos presentes no trato gastrintestinal de humanos e animais, e o seu desequilíbrio tem sido associado às doenças intestinais, tais como: doenças inflamatórias do intestino, síndrome do intestino irritável, doença celíaca e alergias (GAREAU et al., 2010). 
Alguns pesquisadores relacionaram o papel da microbiota intestinal com a indução à tolerância oral envolvida na patogênese da alergia alimentar, devido ao estímulo e desenvolvimento do sistema imunológico; além de também estar envolvida com a resistência às infecções produzidas por diversos patógenos (CONWAY, 2005; O'HARA et al., 2006; ARRIETA et al., 2015). Sabe-se que, no trato intestinal, existe um estado de constante modulação, pois ao mesmo tempo em que o sistema imunológico está pronto para agir contra bactérias patogênicas, também é capaz de se manter tolerante em relação à microbiota residente (WINKLER et al., 2007; AITORO et al., 2017).

Determinados microrganismos vivos, quando ingeridos em certas quantidades podem trazer benefícios à saúde, são os denominados probióticos, como por exemplo, algumas espécies de Bifidobacterium e Lactobacillus. Estudos demonstraram a capacidade de Bifidobacterium spp. utilizar oligossacarídeos fucosilados do leite humano, e favorecer seu crescimento em relação a outras bactérias que fazem parte da microbiota intestinal, tais como Escherichia coli e Clostridium perfringens (DETHLEFSEN e RELMAN, 2011; MARCOBAl et al., 2011).

Espécies de Bacteroides também podem utilizar oligossacarídeos fucosilados como fonte de carbono, o que sugere que a colonização do intestino é auxiliada pelas propriedades do leite, realçando a importância da dieta na determinação da composição da microbiota intestinal humana (MARCOBAl et al., 2011).

Existem evidências de que indivíduos portadores de enfermidades, como doença intestinal inflamatória ou alergias, apresentam microbiota intestinal diferente dos indivíduos saudáveis, com baixa diversidade microbiana. Porém, na maioria dos casos, não é possível afirmar se essa diferença na composição microbiana é característica de algum determinado quadro clínico. Isto sugere maiores estudos para definir as diferenças qualitativas e quantitativas da composição desta microbiota (BISGAARD et al., 2011; AITORO et al., 2017; VAN DEN ELSEN et al., 2019).

Na literatura mundial, são escassos os estudos sobre a composição da microbiota intestinal de crianças com alergia ao leite de vaca. Assim, a identificação da composição dessa microbiota residente poderá fornecer o 
suporte microbiológico necessário para melhor conhecer o impacto que a exclusão do leite de vaca pode provocar. 


\section{CONCLUSÕES}

Com os dados obtidos neste estudo podemos concluir que:

1. As crianças com alergia ao leite de vaca apresentaram maior número de espécies do gênero Clostridium;

2. Pela análise quantitativa, as crianças não alérgicas apresentaram maior número de bactérias pertecentes aos gêneros: Bifidobacterium, e Clostridium Cluster I; aos filos: Firmicutes e Bacteroidetes e a espécie Escherichia coli; e

3. As espécies de Lactobacillus e Bifidobacterium de ambos os grupos de crianças mostraram diversidade genética heterogênea. 


\section{REFERÊNCIAS}

ABBAS, A. K. et al. Imunologia Celular e Molecular, 8ํe ed. Rio de. Janeiro: Elsevier, 2014.

ADLERBERTH, I.; WOLD, A. Establishment of the gut microbiota in Western Infants. Acta. Pediatr., v.98, p.229-238, 2009.

AGANS, R. et al. The distal intestinal microbiota of adolescents is different from that of adults. FEMS Microbiol Ecol., v 77 (2), p. 404-412, 2011.

AGUIRRE, M.; COLLINS, M. D. Lactic acid bacteria and human clinical infection. Journal of Applied Bacteriology., v.75 (1), p.95-107, 1993.

AITORO, R. et al. Gut Microbiota as a target for preventive and therapeutic intervention against food allergy. Nutrients., v 9 (7), p.672, 2017.

ALBENBERG, L. G.; WU, G. D. Diet and intestinal microbiome: associations, functions and implications for health and diseases. Gastroenterol., v 146, p. 1564-1572, 2014.

ARON-WISNEWSKY, J. et al. The importance of the gut microbiota after bariatric surgery- nature reviews. Gastroenterology \& Hepatology., v 16, p.1-10, 2012.

ARRIETA, M. C. et al. Early infancy microbial and metabolic alterations affect risk of childhood asthma. Sci. Transl. Med., v 7 (307), p. 307-152, 2015.

AVERSHINA, E. et al. Major faecal microbiota shifts in composition and diversity with age in a geographically restricted cohort of mothers and their children. FEMS Microbiol Ecol., v 87,p .280 -290, 2014. 
AZAD, M. B.; KONYA, T. Infant gut microbiota and food sensitization: Associations in the first year of life. Clin. Exp. Allergy., v. 45, p.623-643, 2015.

BACKHED, F. et al. Dynamics and Stabilization of the Human Gut Microbiome during the First Year of Life. Cell Host Microbe., v 13;17(5), p. 690-703. 2015.

BALDO, L. Suplementação de cálcio na dieta sem lactose. Sem Lactose, 2008.

BARTUZI, Z. et al. Contribution of molecular allergen analysis in diagnosis of milk allergy. Curr Allergy. Asthma Rep., v 17(7), p 46, 2017.

BERNI CANANI, R. et al. Extensively hydrolyzed casein formula containing Lactobacillus rhamnosus GG reduces the occurrence of other allergic manifestations in children with cow's milk allergy: 3-year randomized controlled trial. J. Allergy Clin. Immunol., v.139, p.1906-1913, 2017.

BISGAARD, $\mathrm{H}$. et al. Reduced diversity of the intestinal microbiota during infancy is associated with increased risk of allergic disease at school age. J. Allergy Clin. Immunol., v. 128, p. 646- 652, 2011.

BOUHNIK, Y. et al. The ability of non-digestible carbohydrates to stimulate fecal bifidobacteria in healthy humans: a double-blind, randomized, placebocontrolled, parallel group, dose-response relationship. Am. J. Clin. Nutr., v 80, p.1658-1664, 2004.

BOUSQUET, J. et al. Practical guide to skin prick tests in allergy to aeroallergens. Allergy., v 67, p 18 - 24, 2012.

BUTEL, M.J. et al. The developing gut microbiota and its consequences for health. Journal of Devel. Origins of Health and Disease., v 9 (6), p. 590-597, 2018. 
BRANUM, A. M.; LUKACS, S. L. Food allergy among children in the United States. Pediatrics., v 124 (6), p 1549-555, 2009.

BRENNER, D. M. et al. The usefulness of probiotics in the treatment of irritable bowel syndrome: a systematic review. Am J Gastroenterol., v.104 (4), p. 491033, 2009.

BRILL, H. Approach to milk protein in infants. Can. Family Physician., v. 54.p. 64-1258, 2008.

BUBNOV, R. V., et al. Comparative study of the probiotic effects of Lactobacillus and Bifidobacterium strains on cholesterol levels, liver morphology and intestinal microbiota in obese mice. J. EPMA ., v.8(4), p. 357-376, 2017.

BUENO, A. L.; CZEPIELEWSKI, M. A. The importance of dietary intake of calcium and vitamin D in growth. J. Pediatr.,v 84(5), p 386-394, 2018.

BUZINARO, E. F. et al. Biodisponibilidade do cálcio dietético. Arq. Bras. Endocrinol. Metab., v. 50 (5), p. 852-861, 2006.

CAFFARELLI, C. et al. Cow's milk protein allergy in children: a practical guide. Ital. J. Pediatr.,v 36 (5), 2010.

CAICEDO. M. Probiotics: protecting the intestinal ecosystem? J. Pediatr., v 147, p. 143-146, 2005.

CALLAWAY, A. et al. Identification of Lactobacilli from deep lesions of caries by means of mass spectrometry specific for PCR and MALDI-TOF mass spectrometry. Clin. Lab., v 59 (11-12), p.1373-1379, 2013.

CALLE, A et al., Anaphylaxis in a lactating infant who is allergic to cow's milk protein. Rev Alerg Mex., v 66, p. 123-127, 2019. 
CASTILLO, A. M. et al. Sepsis por Clostridium septicum em criança com neutropenia auto-imune. Ver. Nascer e crescer., v. 13(4), p.352-354, 2004.

CHEN, C. C. et al. Alterations in the gut microbiota of children with food sensitization in early life. Pediatr. Allergy Immunol., v 27, p. 254-262, 2016.

CHICHLOWSKI, M. et al. Bifidobacteria isolated from infants and cultured in human milk oligosaccharides affect intestinal epithelial function. J. Pediatr. Gastroenterol. Nutr., v.55, p.7-321, 2012.

CLEMENTE, J. C. et al. The impact of the gut microbiota on human health: an integrative view. Cell., v. 148.p.1258-1270, 2012.

CONWAY, K.D. Modulation bacterial mucosa and innate immunity. Mol. Immunol., v 42, p 895-901, 2005.

COTTER, P. D. et al. The impact of antibiotics on the intestinal microbiota, as revealed by the high level of DNA sequencing. Discov. Med., $v 70$, p. 193-199, 2012.

CRUM-CIANFLONE, N. Clostridium innocuum bacteremia in a patient with acquired immunodeficiency syndrome. Am. J. Med. Sci., v.337(6), p. 2-480, 2009.

DAHER, S. et al. Diagnóstico em doenças alérgicas mediadas por lgE. Rev. Bras. Alerg. Imunopatol., v 32(1), p :3-8, 2009.

DE FILIPPO, C. et al. Impact of diet on the formation of intestinal microbiota revealed by a comparative study in children from Europe and rural Africa. Proc. Natl. Acad. Sci. USA., v 107(33), p.14691-14696, 2010.

DE GREGORIS, T. B. et al. Improvement of phylum- and class-specific primers for real-time PCR quantification of bacterial taxa. J. Microbiol. Methods., v. 86, p. 351-356, 2011. 
DEL MORAL, M. G.; Naves, M, E. The role of lipids in development of allergic responses. Immune. Net., v 17 (3), p. 133-143, 2017.

DETHLEFSEN, L.; RELMAN, D. A. Incomplete recovery and individualized responses of the human distal gut microbiota to repeated antibiotic perturbation. Proc. Natl. Acad. Sci. USA., v108, p 454-456, 2011.

DOMINGUEZ- BELLO, M. G. et al. The mode of delivery shapes the acquisition and structure of the initial microbiota in various body habitats in newborns. Proc. Natl. Acad. Sci. USA., v 107 (26), p. 11971-11975, 2010.

DONG, H. et al. Effects of Lactobacillus casei Shirota on immune function. Proc. Nutr. Soc. - Engl. Scot., v. 69. p. E243, 2010.

DUPONT, C. Food allergy: recent advances in pathophysiology and diagnosis. Ann Nutr Metab., v 59 (1), p 8-18, 2011.

ELE, S. et al. Development of sandwich ELISA to test bovine $\beta$-lactoglobulin allergen residues by specific polyclonal antibody against human IgE binding epitopes. Food Chem., v 227, p 33-40, 2017.

ELLEGAARD, K. M. et al. Extensive intra-phylotype diversity in lactobacilli and bifidobacteria from the honeybee gut. BMC Genomics., v 16, p. 284, 2015.

FERNANDES, M. R. et al. Alterations of intestinal microbiome by antibiotic therapy in hospitalized children. Microbial drug resistance., v 23 (1), 2017.

FERNANDÉZ-ORTEGA, M. Consumo de fuentes de calcio en adolescentes mujeres em Panamá. Arch. Latinoam. Nutr., v 58 (3), p 286- 291, 2008.

FERREIRA, C. E. A. et al. Prevalence of Clostridium spp. and Clostridium difficile in children with acute diarrhea in São Paulo City, Brazil. Mem. Inst. Oswaldo Cruz., v 98, p 451-454, 2003. 
FERREIRA, C. T. et al. Food allergy: A practical update from the gastroenterological viewpoint. J. Pediat., v. 83, p. 7-20, 2007.

FIGUEROA-GONZÁLEZ, I. et al. A Probiotics and prebiotics - perceptions and challenges. J. Sci. Food Agric., v.91, p.1341-1348, 2011.

FIOCCHI, A. et al. Diagnosis and justification for action against cow's milk allergy (DRACMA): a summary report J. Allergy Clin. Immunol., v 3, p, 57-61, 2010.

FIOCCHI, A. et al. Cow's milk allergy: towards an update of DRACMA guidelines. World Allergy Organization J., v 9, p 35, 2016.

FLOKSTRA-DE BLOK, B. M. et al. Health-related quality of life of food allergic patients: comparison with the general population and other diseases. Allergy., v 65 (20), p 238- 244, 2010.

FRANCAVILLA R, CALASSO M, et.al. Effect of lactose on gut microbiota and metabolome of infants with cow's milk allergy. Pediatr. Allergy Immunol., v.23, p. 420-427, 2012.

FRANK, D. N. et al. Molecular-phylogenetic characterization of microbial community imbalances in human inflammatory bowel diseases. Proc. Natl. Acad. Sci. USA., v. 104, p. 13780-13785, 2007.

FRICKE, W. F. et al. The sequence of the genome of Methanosphaera stadtmanae reveals why this human argon is restricted to methanol and $\mathrm{H} 2$ for the formation of methane and synthesis of ATP. J. Bact., v.188, p.642-658, 2006.

FUNKHOUSER, L. J., BORDENSTEIN, R. S. Mom knows best: the universality of maternal microbial transmission. PLoS Biol., v. 11, p.e1001631, 2013. 
GARCIA, P. G. et al. Occurrence and antimicrobial drug susceptibility patterns of commensal and diarrheagenic Escherichia coli in fecal microbiota from children with and without acute diarrhea. J. Microbiol., v. 49, p. 46-52, 2011.

GAREAU, M. G. et al. Probiotics and the gut microbiota in intestinal health and disease. Nat. Rev. Gastroenterol. Hepatol., v 7, p 503- 514, 2010.

GILBERT, J.A. et al. Current understanding of the human microbiome. Nature Medicine., v 24, p. 393-400, 2018.

GOLDBOHM, R. A. Et al. Dairy consumption and 10-y total and cardiovascular mortality: a prospective cohort study in the Netherlands. Am. J. Clin. Nutr., v 96, p 615-627, 2011.

GOPALAKRISHNAN, V. et al. The Influence of the Gut Microbiome on Cancer,Immunity, and Cancer Immunotherapy.Cancer Cell.v 33(4),p 570-580, 2018.

GRAY, C. L. et al. Ethnic differences in peanut allergy patterns in South African children with atopic dermatitis. Pediatr. Allergy Immunol., v 26 (8), p 721-730, 2015.

GRZESKOWIAK L, et al.Distinct gut microbiota in southeastern African and northern European infants. J Pediatr Gastroenterol Nutr., v 54, p.812 - 816, 2012.

Guia prático da APLV mediada pela IgE - ASBAI \& SBAN. Rev. Bras. Alerg. Imunopatol., v 35 (6), 2012.

GUSHKEN, A. K. et al. Double-blind, placebo-controlled food challenges in Brazilian children: adaptation to clinical practice. Allergol Immunopathol., $v$ 41, p 94-101, 2013.

HAARMAN, M.; KNOL, J. Quantitative real-time PCR assays to identify and 
quantify fecal Bifidobacterium species in infants receiving a prebiotic infant formula. Appl. Environ. Microbiol., v 71 (5), p. 2318-2324, 2005.

HALL, M. A. et al. Factors influencing the presence of faecal lactobacilli on early infancy. Arch. Dis. Child., v.65, p. 88-185, 1990.

HARO, C.; MÓNACO, M.E.; MEDINA. M. Lactobacillus casei beneficially modulates the immunocagulative response in a model of endotoxemia. Blood Coagul Fibrinolysis., v.29 (1), p. 104-110, 2018.

HEINE, R. G. et al. Cow's milk allegy in infancy. Curr. Opin. Allergy Clin. Immunol., v. 2, p. 25-217, 2002.

HILL, M. J.; DRASAR, B. S. The normal colonic bacterial flora. Gut., v.16, p.318-323, 1975.

HOPPU, U. et al. Dietary habits and nutrient intake of finnish adolescents. Pulic Health Nutri., v 13 . p 965- 972, 2010.

HUDA, M. N. et al. Microbiota of feces and vaccine responses of infants. Pediatrics., v. 134 (4), p. 72-362, 2014.

INUO C. et al. Tolerability of partially and extensively hydrolysed milk formulas in children with cow's milk allergy. Asia Pac J Clin Nutr., v.28(1), p.:49-56, 2019.

IOM - Institute of Medicine of the National Academy. Dietary Reference Intakes for calcium and vitamin D. Report Brief. November, 2010.

ISOLAURI, E. et al. Elimination diet in cow's milk allergy: risk for impaired growth in youngchildren. J. Pediatr., v 132, p 1004- 1008, 1998.

JACKSON, M. S. et al. Comparison of two selective media for the detection and enumeration of Lactobacilli in human faeces. J. Microbiol Meth., v 51, p 313- 
$321,2002$.

JACOUTON, E. et al. Estirpe probiotic Lactobacillus casei BL23 probiotic strain prevents colorectal cancer associated with colitis. Frontiers in immunol., v. 4, p. $1553,2017$.

JEONG, K. et al. Age-Based causes and clinical characteristics of immediatetype food allergy in korean children. Allergy Asthma Immunol. Res., v 9(5), p. 423-430, 2017.

JIMENEZ, E. et al. Is the meconium of healthy newborns really sterile? Res. Microbiol., v 159 (3), p.187-193, 2008.

KALLIOMÄKI, M. et al. Probiotics during the first 7 years of life: a cumulative reduction in the risk of eczema in a randomized, placebo-controlled study. J. Allergy Clin. Immunol., v.119 (4), p. 21-1019, 2007.

KANAI, T. et al. Diet, microbiota and inflammatory bowel disease: Japanese food lessons. Korean J Intern Med., v 29(4), p. 409- 415, 2014.

KANSU, A, et al. A consensus statement on the diagnosis, treatment and monitoring of cow's milk protein allergy among infants and children in Turkey. J. Pediatr., v 58(1), p 1-11, 2016.

KANG, S. et al. Fecal microbiota dysbiosis in patients with Crohn's disease as revealed by a custom phylogenetic microarray. Inflamm Bowel Dis., v 16, p. 2034-2042, 2010.

KENDLER, M. et al. Comparison of fecal microflora in children with atopic eczema/dermatitis syndrome according to IgE sensitization to food. Pediatr. Allergy Immunol.,v.17, p.141-147, 2006.

KIEWIET, M. B. G . et al. Partially hydrolyzed whey proteins prevent clinical symptoms in a cow's milk allergy mouse model and enhance regulatory $T$ and $B$ 
cell frequencies. Mol. Nutr. Food Res., v 61(11), 12p, 2017.

KIM, K. S.; HONG, S. W. Dietary antigens limit mucosal immunity by inducing regulatory $T$ cells in the small intestine. Science, v 351, p. 858-863, 2016.

KORPELA, K. et al. Selective maternal seeding and environment shape the human gut microbiome. Genome Res., v 28(4), p. 561-568, 2018.

KUISMA, J. et al. Effect of Lactobacillus rhamnosus GG on inflammation of the ileal pouch and microbial flora. Aliment Pharmacol Ther., v. 17 (4), p. 15-509, 2003.

KWEON, M. N. Et al. Systematically derived intestinal CD4 (+) Th2 cells play a central role in STAT6-mediated allergic diarrhea. J. Clin. Invest., v 106, p 199206, 2000.

LANDMAN, C. et al. Gut microbiota: Description, role and pathophysiological implications. Rev. Med. Intern., v 37(6), p. 418- 423, 2015.

LATTINEN, K. et al. Management of foos allergy: vitamin, fatty acids or probiotics? Eur J. Gastroenterol Hepatol., v 17, p 1305-1311, 2017.

LE CHATELIER, E. et al. The richness of the human gut microbiome correlates with metabolic markers. Nature, v 500 (7464), p. 541-546, 2013.

LEE, D. H. et al. Quantitative detection of residual E. coli host cell DNA by RealTime PCR. J. Microbiol. Biotechnol., v.20, p.1463-1470, 2010.

LEE, J. B. Regulation of IgE-mediated food allergy by IL-9 producing mucosal mast cells and type 2 innate lymphoid cells. Immune New., v 16 (4), p 211-218, 2016.

LINDSTROM, M. et al. Clostridium botulinum in cattle and dairy products. Crit. Rev. Food., v. 50(4), p. 281-304, 2010. 
LIVINGSTON, S. J. et al. New medium for selective and presumptive identification of the Bacteroides fragilis group. J. Clin. Microbiol., v 7, p 448453,1978 .

LIU, C. et al. Rapid identification of the species of the Bacteroides fragilis group by multiplex PCR assays using group- and species-specific primers. FEMS Microbiology Letters., v. 222, p. 9-16, 2003.

MANDAL, R. S. et al. Metagenomic surveys of gut microbiota. Genomics Proteomics Bioinformatics. V. 13, p. 148-158, 2015.

MARCOBAL, A. et al. Bacteroides in the infant gut consume milk oligosaccharides via mucus-utilization pathways. Cell Host Microbe., v 10, $p$ 507-514, 2011.

MARIAT, D. et al. The Firmicutes/ Bacteroides ratio of the human microbiota changes with age. BMC Microbiol., v.9,123-128, 2009.

MARTINI, L. A. et al. Prevalence and correlates of calcium and vitamin D adequacy in adolescentes, adults, and elderley from the Health Survey. Nutrition, v 29, p. 845-850, 2013.

MATANGKASOMBUT, P. et al. Detection of $\beta$-lactoglobulin in human breast milk 7 days after the ingestion of cow's milk. Paediatr Int Child Health., $v$ 37(3), p 199-203, 2017.

MAZMANIAN, S. K . et al. An immunomodulatory molecule of symbiotic bacteria directs the maturation of the host's immune system. Cell., v 122 (1), p. 107-118, 2005.

MEVISSEN-VERHAGE, E. A. et al. Bifidobacterium, Bacteroides, and Clostridium spp. in fecal samples from breast-fed and bottle-fed infants with and without iron 
supplement. J Clin Microbiol., v 25, p. 285-289, 1987.

MILLS S. et al. Milk intelligence: Mining milk for bioactive substances associated with human health. Int Dairy J., v 21, p 377-401, 2011.

MIRAGLIA DEL GLUDICE, M. et al. Flavor, relative palatability and components of hydrolyzed cow's milk formula and amino acid-based formula. Ital J Pediatr., v 41(42), 2015.

MORIYAMA, T. Diversity of Food Allergy. J Nutr Sci Vitaminol (Tokyo)., v 61,p. 106-108, 2015.

MUNIZ, L. C. et al. Consumo de leite e derivados entre adultos e idosos no Sul do Brasil: um estudo de base populacional. Ciênc Saúde Coletiva., v18 (12),p 3515-3522, 2013.

MURANO, A., et al. EAACl - Food Allergy and Anaphylaxis Guidelines: diagnosis and management of food allergy. Allergy., v 69 (8), p 1008-1025, 2014.

NANJAPPA, S. et al. Clostridium septicum gas gangrene in colon cancer: Importance of early diagnosis. Case Rep Infect Dis., v.2015, 3p, 2015.

NEBRA, Y. et al. A new selective medium for Bifidobacterium spp. App. Env. Microbiol., v 65, p 5173-5176, 1999.

NORO, G. et al. Fatores ambientais que afetam a produção e a composição do leite em rebanhos assistidos por cooperativas no Rio Grande do Sul. Revista Brasileira de Zootecnia., v.35, p.1129- 1135, 2006.

NOWAK-WEGRZYN, A .; SAMPSON, H. A. Adverse reactions to food. Med Clin North Am. v 90 (1), p. 97- 127, 2006.

O'HARA, A. et al. The gut flora as a forgotten organ. Reports Emb., v 7, p 688- 
693, 2006.

PAOLO, C. C. F; MALTZ, M. Estudo de Lactobacillus no biofilme oral. 2009. Dissertação (Doutorado). Universidade Federal do Rio Grande do Sul. Faculdade de Odontologia.

PEREIRA, P. C. Milk nutritional composition and its role in human health. Nutrition., v 30(6), p 619-627, 2014.

PETERSEN, C. et al. Defining dysbiosis and its influence on host immunity and disease. Cell Microbiol., v 16, p 1024-1033, 2014.

PETERSON, D. A. Ig A response to symbiotic bacteria as mediator of intestinal homeostasis. Cell Host Microbe., v 2, p. 328 - 339, 2007.

PHILIPPI, ST. Pirâmide dos alimentos. Fundamentos básicos da nutrição. Barueri Manole., ed 2, 2013.

PLUNKETT, C. H.; NAGLER, C. R. The Influence of the microbiome on allergic sensitization to food. J. Immunol., v 198, p. 581-589, 2017.

POEHLEIN, A. et al. The complete Clostridium acetone genome sequence: A lost link between the autotrophic acetogens containing Rnf and cytochrome. mBio., v 6 (5), p 1168-15, 2015.

PONNUSAMY, K. et al. Microbial community and metabolomic comparison of irritable bowel symdrome faeces. J. Med. Microbiol., v.60, p.817-827,2011.

PRAKASH, S. et al. The gut microbiota and human health with an emphasis on the use of microencapsulated bacterial cells. J. Biomed. Biotechnol. , v 2011, 9812142011.

QIN, J. et al. A human gut microbial gene catalogue established by metagenomic sequencing. Nature., v 464, p.59-65, 2010. 
RINNE, M. M et al. Similar bifidogenic effects of partially hydrolyzed infant formula supplemented with prebiotics and breastfeeding in the baby's intestinal microbiota. FEMS Immunol Med Microbiol., v 43 (1), p. 59- 65, 2005.

RINTTILA, T. et al. Development of an extensive set of $16 \mathrm{~S}$ rDNA-targeted primers for quantification of pathogenic and indigenous bacteria in faecal samples by real-time PCR. Journal of Applied Microbiology., v. 97,p. 11661177,2004 .

RONA, J. et al. The prevalence of food alergy: a meta- analysis. Allergy Clin. Immunol. J., v.120, p. 638-646, 2007.

RUTAYISIRE, E. et al. The mode of delivery affects the diversity and colonization pattern of the intestinal microbiota during the first year of the infant's life: a systematic review. BMC Gastroenterol ., v.16, p.86, 2016.

SANTALHA, M. et al. Alergia alimentar em idade pediátrica. Nascer e Crescer., v.22 (2), p. 75 - 79, 2013.

SAMPSON, H. A. Update on food allergy. Curr. Rev. allergy Clin immunol., v 113, p 805-819, 2004.

SÁNCHEZ-VALVERDE, F. et al. Factors Associated with the Development of Immune Tolerance in Children with Cow's Milk Allergy. Int Arch Allergy Immuno., v 16, p. 1-7, 2019.

SATOKARI, R. et al. Bifidobacterium DNA and Lactobacillus in human placenta. Lett Appl Microbiol., v 48 (1), p. 8- 12, 2009.

SCHIESS, S. A. et al. Introduction of potentially allergenic foods in the Infant's diet during the first years of life in five European countries. Ann Nutr Metab., $v$ 58(2), p 109-117, 2011. 
SCHELLENBERGER, S. et al. Metabolic responses of novel cellulolytic and saccharolytic agricultural soil bacteria to oxygen. Environ. Microbiol., v 12(4), p.845-861, 2010.

SICHERER, S. H.; SAMPSON, H. A. Allergy food. J Allergy Clin Immunol., V 117(2), p 470-475, 2006.

SICHERER, S. H. Epidemiology of food allergy. J Allergy Clin Immunol v.127 (3), p 594-602, 2011.

SGARBIERI, V. C. Proteínas em alimentos protéicos: propriedadesdegradações-modificações. São Paulo: Varela; 1996. 517p.

SHAKER M. New insights into the allergic march. Curr Opin Pediatr., v 26(4), p 516-520, 2014.

SHULMAN, S. T. et al. Theodor Escherich: the first pediatric infectious diseases physician? Clin Infect Dis., v 45, p 1025- 1029, 2007.

SILVA. M. et al. Antimicrobial substance of a human strain of Lactobacillus. Antimicrob. Agents Chemother., v.31(8), p.3-1231, 1987.

SIRAGUSA, G. R. et al. Quantitative analysis of the intestinal bacterial community in one-to three week old commercially reared broiler chickens fed conventional or antibiotic free vegetables based diets. J. App. Microbiol., v. 102, p.1138-1149, 2007.

SJOGREN, Y. M.; JENMALM, M. C., BOTTCHER, M. F., et al. Altered early infant gut microbiota in children developing allergy up to 5 years of age. Clin Exp Allergy., v.39, p. 518-526, 2009.

SMITH- BROWN, P. et al. Mothers secretor status affects development of childrens microbiota composition and function: A pilot study. PLoS ONE. Journal.Pone., v.11(9), 2016. 
SOCRANSKY, S. S. et al. Use of checkerboard DNADNA hybridization to study complex microbial ecosystems. Oral Microbiol. Immunol., v 19, p. 352-362, 2004.

SONGJINDA, P. et al. Differences in the development of the intestinal microbiota among allergic and non-allergic children: a pilot study in Japan. Biosci Biotechnol Biochem., v 71 (9), p. 2338- 2342, 2007.

SOUZA, G. T. et al. Dietary whey protein lessens several risks factors for metabolic diseases: a review. Lipids Health Dis.v 11, p 67, 2012.

SRIVASTAVA, I. et al. Spontaneous gas gangrene by C. septicum: literature review. Anaerobe., v 48, p.165-171, 2017.

STARK, P. L; LEE, A. The microbial ecology of the large bowel of breast-fed and formula-fed infants during the first year of life. J. Med. Microbiol., v.15, p.189-203, 1982.

STEWART, J.A.et al.Investigations into the influence of host genetics on the predominant eubacteria in the faecal microflora of children. J Med Microbiol., v.54,p.1239 -1242,2005.

STEFKA, A. T. et al. Commensal bacteria protect against sensitization of food allergens. Proc. Natl. Acad. Sci. EUA., v.111, p.13145-13150, 2014.

SZAJEWSKA, $\mathrm{H}$. et al. Use of probiotics for managing acute gastroenteritis: A position paper from the ESPGHAN Working Group on Probiotics and Prebiotics. J. Pediatric Gastroenterol. Nutrition., v.58(4),p. 9-531, 2014.

TAMBURINI, S. et al. The microbiome in early life: implications for health outcomes. Nat Med., v 22(7), p. 713- 722, 2016.

TAYLOR-BLACK, S.; WANG, J. The prevalence and characteristics of food 
allergy in urban minority children. Ann Allergy Asthma Immunol., v 109 (6), p 7-431,2012.

$\mathrm{TOH}$, Z. Q. et al. Probiotic therapy as a novel approach for allergic disease. Front Pharmacol., v. 3, p.171,2012.

TURNBAUGH, P. J. et al. The human microbiome project. Nature., v 7164, p 804- 810, 2007.

UNCUOGLU, A. et al. Tolerance to boiled and fermented cow's milk in children with IgE-mediated and non-IgE-mediated cow's milk allergy in patients less than two years of age. Allergol Immunopathol (Madr)., v 45(6), p 560-566, 2017.

USAI-SATTA, P. et al. Lactose malabsorption and intolerance: What should be the best clinical management? World $\mathbf{J}$ Gastrointest Pharmacol Ther., $v$ 3, p 29-33, 2012.

VANDAMME, P. et al. Polyphasic taxonomy, a consensus approach to bacterial systematic. Microbiological Reviews., v. 60, p.407-438,1996.

VAN DEN ELSEN, L.W.J.et al. Shaping the Gut Microbiota by Breastfeeding: The Gateway to Allergy Prevention?. Front Pediatr.,v.27.p.7-47, 2019.

VAN HUL, M. et al. The reduction of obesity, diabetes, and steatosis over cinnamon and grape marc are associated with changes in intestinal microbiota and intestinal barrier markers. Am J Physiol Endocrinol Metab., v 314(4), p.334-352, 2017.

VANDENPLAS, Y. Lactose intolerance. Asia Pac J Clin Nutr., v 24(1), p 9-13, 2015.

VENTER, C. et al. Impact of elimination diets on nutrition and growth in children with multiple food allergies. Curr Opin Allergy Clin Immunol., v 17(3), p 220 226, 2017. 
WALIGORA-DUPRIET, J. A. et al. Diversity of gut Bifidobacterium species is not altered between allergic and non-allergic French infants, Anaerobe., v.17, p. 91-96, 2011.

WANG, Y. et al. The culture supernatant of Lactobacillus Rhamnosus GG improves acute alcohol-induced intestinal permeability and liver injury. American J. Physiol., v . 303 (1), p.32- 41, 2012.

WANKE, M.; SZAJEWSKA, H. Probiotics to prevent health-associated diarrhea in children: a meta-analysis of randomized clinical trials. Pediatr. Polska., v. 89, p.16-8, 2014.

WASERMAN, S.; WATSON, W. Food allergy. Allergy, Asthma \& Clinical., v 7, p 1-7, 2011.

WINKLER, I. Interpreting the incompatibility negativity (MMN). J. Psychophysiol., v 21, p. 147- 163, 2007.

WINKLER, P. et al. Molecular and cellular basis of microflora host interactions. J. Nutr., v.137, p. 756S-772S, 2007.

WOOD, R. A. et al. The natural history of food allergy. Pediatrics., v 111, p 1631-1637, 2013.

YOUN, S. Y. et al. Evaluation of the PCR method for identification of Bifidobacterium species. Lett. Applied Microbiol., v 46(1), p. 7-13, 2008.

YU, Z. T., et al. The major fucosylated human milk oligosaccharides have prebiotic properties in cultured infant microbiota. Glycobiology., v 23, p. 169177, 2013. 